Sādhanā Vol. 39, Part 5, October 2014, pp. 1185-1200. (C) Indian Academy of Sciences

\title{
Exterior beam-column joint study with non-conventional reinforcement detailing using mechanical anchorage under reversal loading
}

\author{
S RAJAGOPAL* and S PRABAVATHY \\ ${ }^{1}$ Department of Civil Engineering, Mepco Schlenk Engineering College, Sivakasi \\ 626005 , India \\ e-mail: srajagopals@gmail.com
}

MS received 23 April 2013; revised 20 November 2013; accepted 20 November 2013

\begin{abstract}
Reinforced concrete structures beam-column joints are the most critical regions in seismic prone areas. Proper reinforcement anchorage is essential to enhance the performance of the joints. An attempt has been made to appraise the performance of the anchorages and joints. The anchorages are detailed as per ACI-352 (mechanical anchorages), ACI-318 (conventional bent hooks) and IS-456 (conventional full anchorage). The joints are detailed without confinement in group-I and with additional $\mathrm{X}$-cross bar in group-II. To assess the seismic performance, the specimens are assembled into two groups of three specimens each and were tested under reversal loading, The specimen with T-type mechanical anchorage (Headed bar) and T-type mechanical anchorage combination with $\mathrm{X}$-cross bar exhibited significant improvement in seismic performance: load-displacement capacity, displacement ductility, stiffness degradation, controlled crack capacity in the joint shear panel and also reduced congestion of reinforcement in joint core.
\end{abstract}

Keywords. Reinforced concrete; beam-column joint; seismic susceptibility; mechanical anchorage; ductility; reversal loading.

\section{Introduction}

Beam-column joints in seismically susceptible zones are critical regions in the reinforced concrete framed structure. Proper anchorage and joint details of reinforcement are essential. The innovative joint designs that are able to reduce congestion of reinforcement in the joint are desirable. ACI-352 (2002) recommends additional research on use of T-headed bar (mechanical anchorage) in design of beam-column joints in concrete structures. The investigation of the exterior beam-column joint reinforcement bar with $90^{\circ}$ standard bent hooks anchorage and mechanical anchor for joint core under reversal loadings has been a research area for many years. Some of the analytical studies and experimental studies carried out so far are indicated below.

*For correspondence 
Park \& Paulay (1975) recommend the detailing of joints for the earthquake resistance structures using bent-up bars, stub-beam with bent-up bars and mechanical anchorage for serving as anchorage as well as effective ties for confinement in the joint core of the exterior beam-column joints. Paulay (1989) suggests that, as in the case of linear element, joint shear reinforcement is necessary to sustain a diagonal compression field rather than to provide confinement to compressed concrete in joint core. Tsonos et al (1993) suggested that the use of crossed inclined bars in the joint region was one of the most effective ways to improve the seismic resistance of exterior beam-column joints. Wallance et al (1998) suggestion of use of headed reinforcement had eased specimen fabrication, concrete placement and the behaviour was as good as than similarly constructed specimens with standard $90^{\circ}$ hooks for beam-column corner joint. Chutarat \& Aboutaha (2003) reported that the use of straight-headed bars in the exterior beam-column joint for cyclic response were very effective in relocating potential plastic regions. Murty et al (2003) reported that the ACI standard hooks for anchorage of the longitudinal beam bar with haircliptype transverse joint reinforcement were more effective and this combination of anchorage with joint reinforcement is easy to construct and can be used in moderate ductility demand situations. Uma \& Sudhir (2006) in their review of codes of practices considered ACI318, NZS 3101: Part-1 and Eurocode-8 EN1998-1 regarding the design and detailing aspects of interior and exterior beam-column joint. Lee \& Yu (2009) proposed extension of ACI design methods to cover the use of mechanical anchorage for eccentric beam-column joints. They reported that cyclic behaviour of exterior beam-column joints can be significantly improved by attaching double mechanical device on each beam bar within the joint. Bindhu et al (2008) in their experimental investigations validated with analytical studies carried out by finite element model indicate that additional inclined reinforcement bar improves the seismic performance of the exterior reinforced concrete beam-column joints. The use of headed bars has become increasingly popular for relatively large reinforced concrete (RC) structures that are exposed to extreme loads such as strong earthquakes or blasts, often providing an adequate solution to steel congestion (Chun et al 2007; Kang et al 2009, 2010). Sagbas et al (2011) in their FEA Computational analysis compared with experimental test results seismically and non-seismically designed joint detailed for the effect of shear deformations. Misir \& Kahraman (2013) proposed a seismic strengthening technique for non-seismically detailed beam-column joints of existing reinforced concrete buildings using pre-fabricated SIFCON composite blocks.

The anchorage requirements for the beam longitudinal reinforcement bar and joint core details are the main issues found from the literature reviewed for the problem of reinforcement congestion in the beam-column joint core region of seismic prone areas. An attempt has been made to evaluate the performance of the exterior beam-column joint by replacing the $90^{\circ}$ standard bent bar anchorages by T-type mechanical anchorage with additional X-bar in the beam-column joint core for the low seismic prone area. It is found that these combinations effectively reducing the reinforcement congestion in joint core as well improve the seismic performance without compromising the ductility and stiffness of the beam-column joints under reversal loading.

\section{Testing program}

The specimens are divided into two groups, each group comprising three specimens, with different anchorages. The anchorage details of specimens are designated as A, B and C and joint details designated as 1 and 2. The specimen with T-type headed bar followed as per ACI-352 (2002) is designated as detail-A, the specimen with conventional $90^{\circ}$ bent hook followed as per ACI-318 (2011) is designated as detail-B and the specimen with full anchorage followed as per 
IS-456 (2000) is designated as detail-C. The joint core of the specimen without confinement reinforcement is designated as joint detail- 1 and the joint core of the specimen with additional $\mathrm{X}$-cross reinforced bar is designated as joint detail-2.

\section{Experimental test set-up}

The half-scale exterior beam-column joint specimen testing was carried out at MEPCO Engineering College, Sivakasi, INDIA. The joint assemblage was subjected to reversal loading using two numbers of 25 ton $(250 \mathrm{kN})$ capacity hydraulic jacks. The specimen was oriented as described below.

The column part was kept horizontal and the beam part was kept vertical direction as shown in figure 1. Both ends of the RCC columns were restrained both in vertical and also in the horizontal directions by using strong built-up steel boxes which in turn are connected to the reaction floor using holding down anchor bolts. To facilitate the application of reversal load (Left Hand Side-LHS and Right Hand Side-RHS) on either side of the RCC beam, the hydraulic jacks were connected to the strong steel frame with mechanical fasteners. The RCC beam was loaded as shown in the figure 1. The Linear Variable Differential Transducer (LVDT) was connected on either side of the specimen to monitor the displacements. The testing was load controlled with load increment of 1-ton $(10 \mathrm{kN})$. The specimens were tested till it reached its maximum failure capacity.

\section{Details of test specimens}

All the specimens were identical in size and the beam sizes were $200 \mathrm{~mm} \times 300 \mathrm{~mm}$ and cross section of the column were $300 \mathrm{~mm} \times 200 \mathrm{~mm}$ as shown in figure 2 . The length of the beam was $1200 \mathrm{~mm}$ from the column face and the height of the column was $1500 \mathrm{~mm}$. The various types

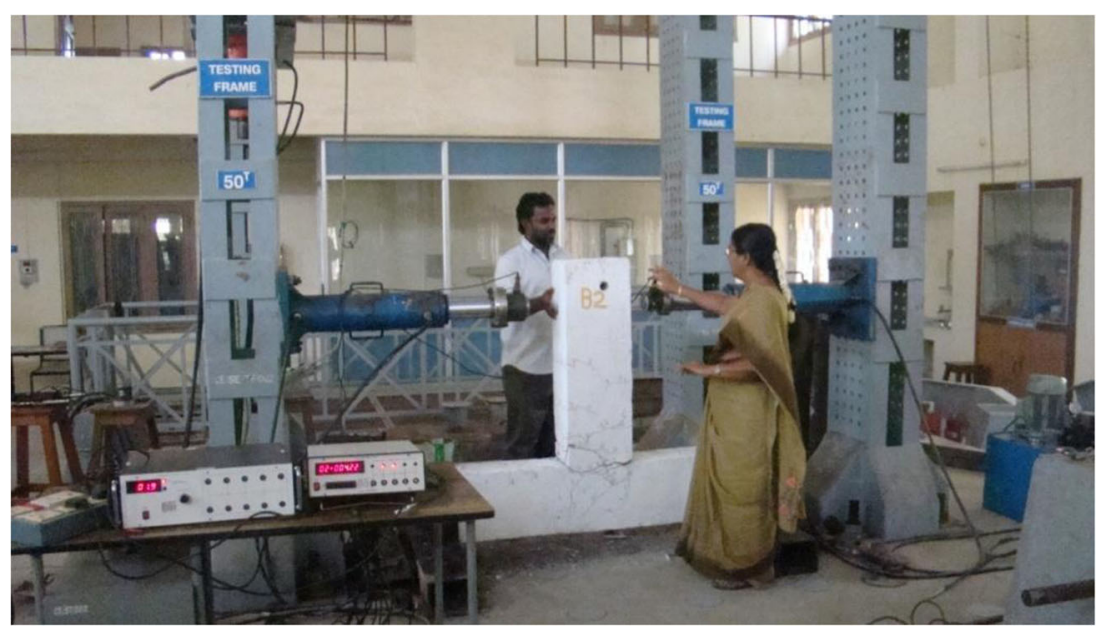

Figure 1. Experimental set-up. 


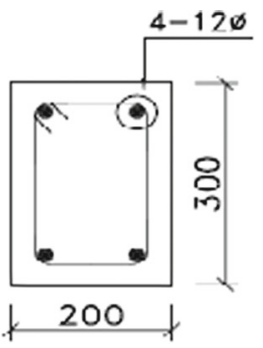

TYPICAL COLUMN CROSS SECTION

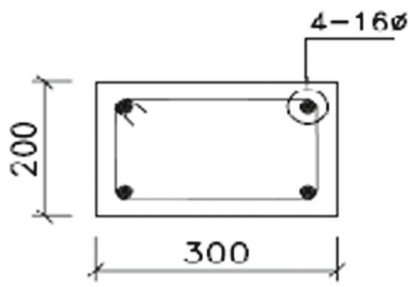

IYPICAL BEAM CROSS SECTION

Figure 2. Beam and column size.

of anchorages used has been shown in figures 3-5 and the joint details used has been shown in figure 6. In group-I, the anchorages $\mathrm{A}, \mathrm{B}$ and $\mathrm{C}$ were combined with joint detail-1 and these specimens were named as A1, B1and C1. Similarly in group-II, the anchorages A, B and C were combined with joint detail-2 and these specimens were named as A2, B2 and C2.

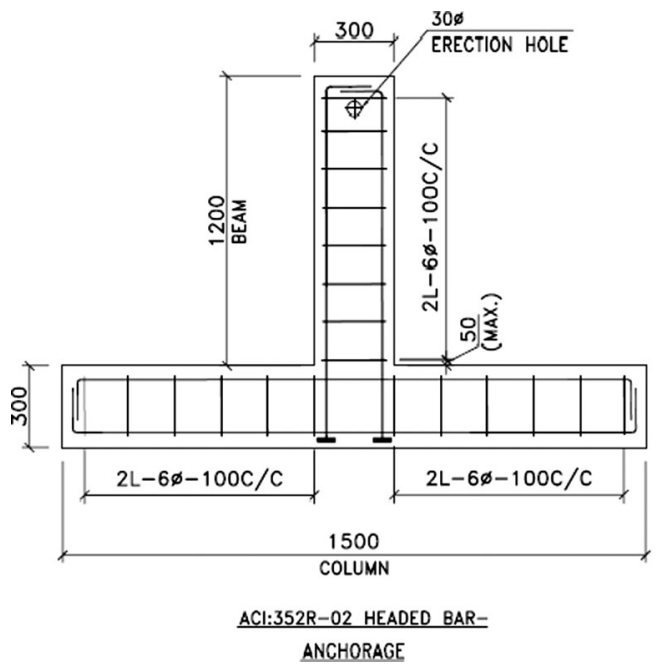

Figure 3. Specimen type-A. 


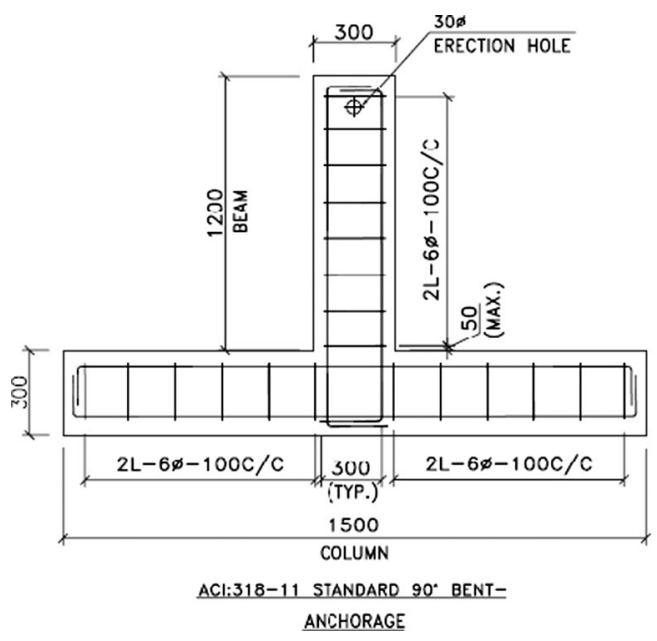

Figure 4. Specimen type-B.

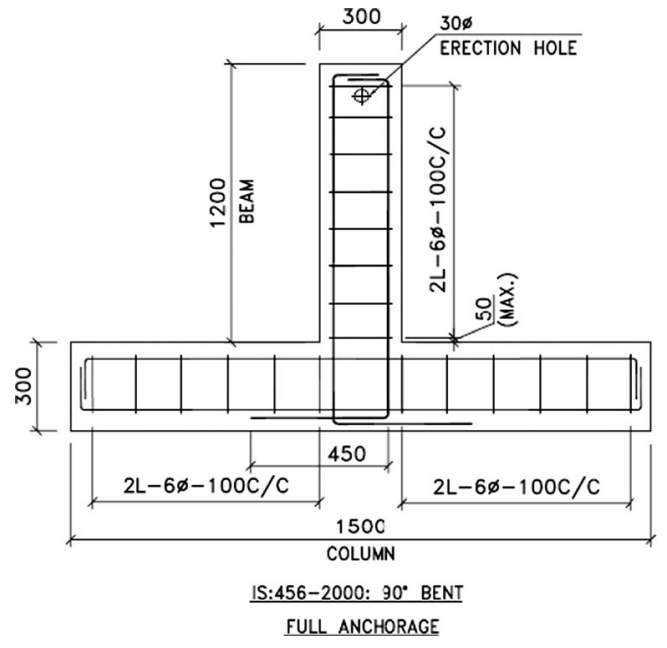

Figure 5. Specimen type-C.

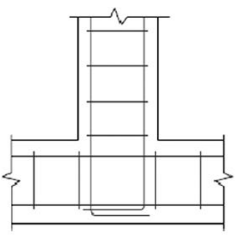

JOINT DETAIL-1

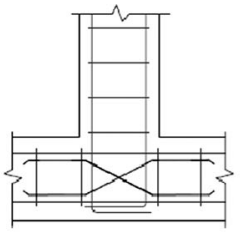

JOINT DETAIL-2

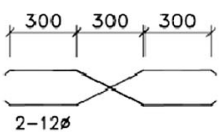

CROSS BAR
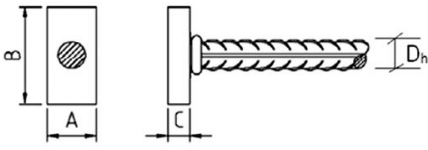

$B=70 \mathrm{~mm}, A=40 \mathrm{~mm}, C=16 \mathrm{~mm}$

$D_{\mathrm{h}}=16 \mathrm{~mm}$ Diameter

Figure 6. Joint reinforcement and headed bar. 

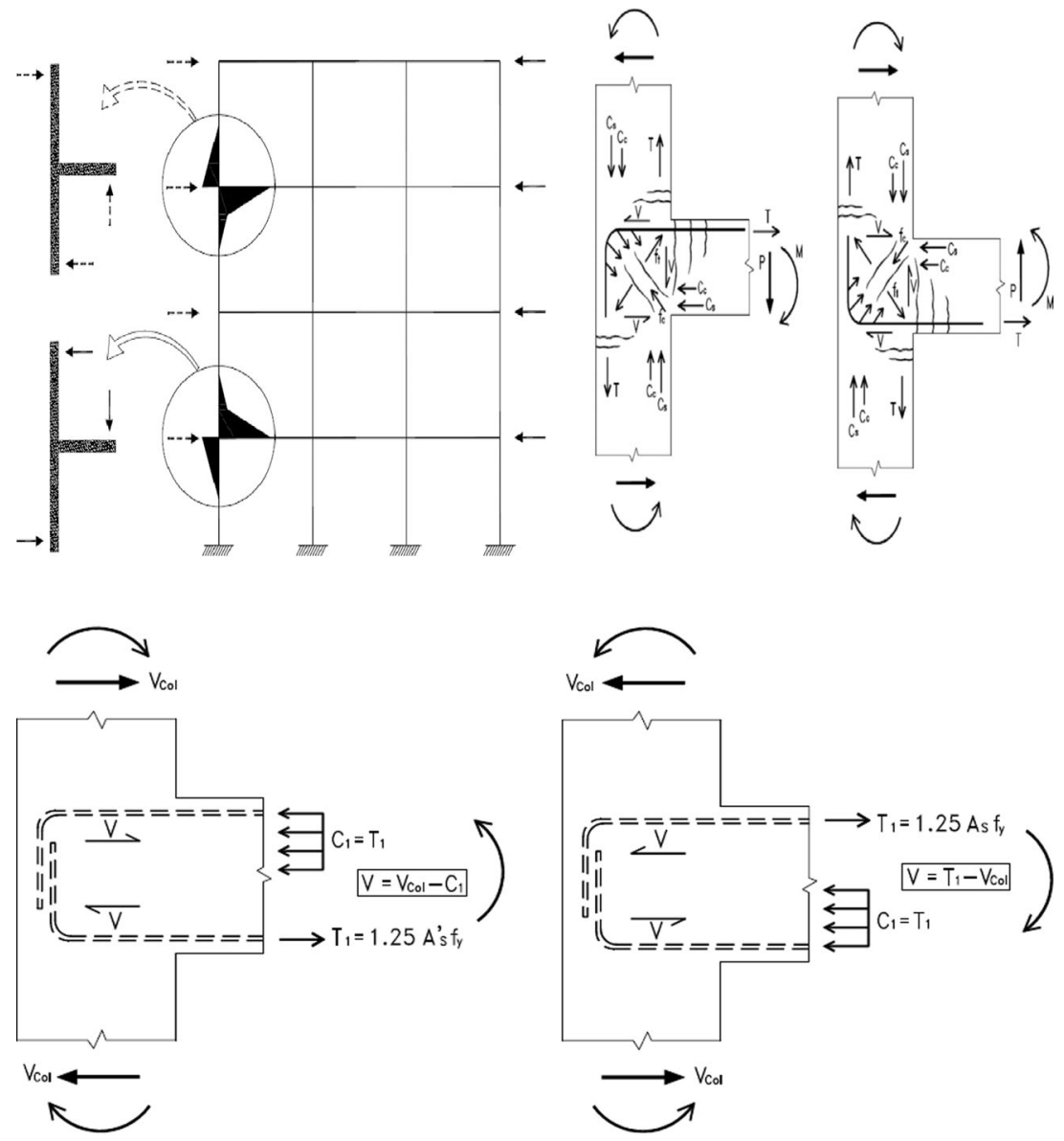

Figure 7. Typical reinforced concrete frame right and left side sway joint forces.

\section{Materials used}

Concrete was made with 43 Grade cement with river sand and $20 \mathrm{~mm}$ downgraded coarse aggregate.

The quantities of material per cubic meter of concrete were following:

- Cement $=435.45 \mathrm{~kg}$

- Fine aggregate $=626.673 \mathrm{~kg}$

- Coarse aggregate $=1188.22 \mathrm{~kg}$

- Water $=191.6 \mathrm{~kg} / \mathrm{m}^{3}$

- Water/cement ratio $=0.45$.

The $28^{\text {th }}$ day average cube compressive strength was $28.30 \mathrm{MPa}$.

The reinforcement bars used were 6, 8, 12 and $16 \mathrm{~mm}$ diameter of grade Fe-415 and welded joint T-type mechanical anchorage (Headed bar) used were E410 as shown in figure 6. 
Table 1. Provided and required development lengths for beam bars used for joint subassemblies.

\begin{tabular}{|c|c|c|c|c|c|}
\hline $\begin{array}{l}\text { Codes } \\
\text { details }\end{array}$ & Equations & $\begin{array}{c}\text { Required } \\
\text { development } \\
\text { length }(\mathrm{mm})\end{array}$ & $\begin{array}{c}\text { Provided } \\
\text { development } \\
\text { length }(\mathrm{mm})\end{array}$ & $\begin{array}{l}\text { Beam bars } \\
\text { anchorage } \\
\text { type }\end{array}$ & $\begin{array}{l}\text { Specimen } \\
\text { types with } \\
\text { groups }\end{array}$ \\
\hline$A C I-352$ & $L_{d t}=\frac{3}{4} *\left(L_{d h}\right)$ & 200.63 & 250.00 & $\begin{array}{l}\text { T-Type mechanical } \\
\text { anchorage }\end{array}$ & $\overline{\text { A1-I \& A2-II }}$ \\
\hline$A C I-318$ & $L_{d h}=\frac{\alpha * f_{y} d_{b}}{6.2 \sqrt{f_{c}^{\prime}}}$ & 267.50 & 272.00 & $\begin{array}{l}\text { 90-degree standard } \\
\text { bent anchorages }\end{array}$ & B1-I \& B2-II \\
\hline$I S-456$ & $L_{d}=\frac{\phi \sigma_{s}}{4 \tau_{b d}}$ & 644.73 & 710.00 & $\begin{array}{l}\text { 90-degree standard bent } \\
\text { full anchorage }\end{array}$ & C1-I \& C2-II \\
\hline
\end{tabular}

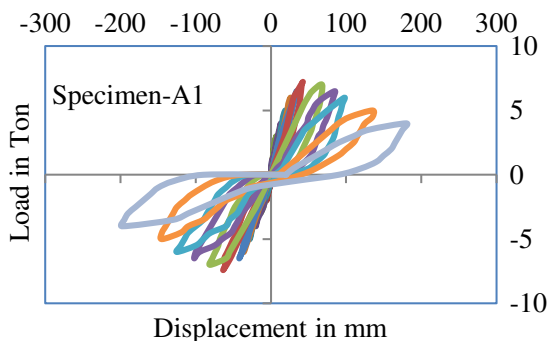

Figure 8. Load vs displacment (A1).

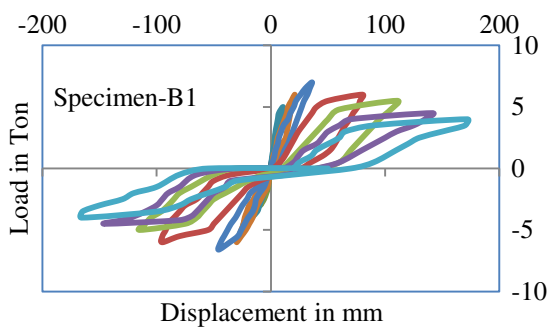

Figure 9. Load vs displacment (B1).

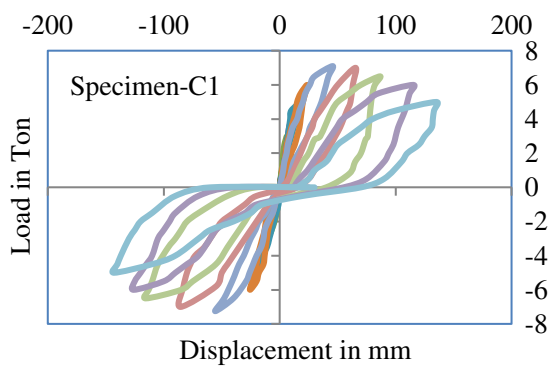

Figure 10. Load vs displacment (C1). 


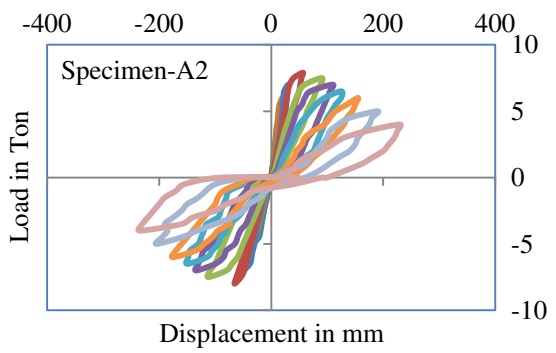

Figure 11. Load vs displacment (A2).

\section{Critical joint mechanism details}

A particularly moderate and severe ground shake situation can arise in certain exterior beamcolumn joints of plane multistory frames when these are subjected to seismic loading. The external action and the corresponding internal forces generated around such a joint are indicated in figure 7 . The following notations refer to the stress resultants. $T$-Tension force in the reinforcement, $C_{c}$-compression force in the concrete, $C_{s}$-compression force in reinforcement and $V$-shear force, subscript ' $b$ ' for beam and ' $c$ ' for column. From the position of the stress resultants it is apparent that diagonal tension and compression stress $\left(f_{c}\right.$ and $\left.f_{t}\right)$ are induced in the shear panel zone of the joint.

\section{Beam-column joint core reinforcement}

\subsection{Joint core reinforcement anchorage}

ACI-ASCE Committee 352 (2002) classified beam-column joints as Type-1 and Type-2. For joints of Type-1, no inelastic deformations are anticipated whereas joints of Type- 2 are designed to sustain strength under deformation reversals into the inelastic range. It should be note that this paper deals only with Type- 2 joints, i.e. seismic beam-column joints. The ACI report specifies that for beams with Type- 2 connections, the critical section for development length of reinforcement either hooked or headed should be taken at the outside edge of the column core. The development length $\left(L_{d h}\right)$ measured from the critical section should be computed as shown in table 1 . The development length $L_{d t}$ of a headed bar should be taken as $3 / 4$ of the value computed for hooked bars. In headed bar, the bar head should be located in the confined core within 2 in. $(50 \mathrm{~mm})$ from the back of the confined core. The minimum development length $L_{d t}$ should not

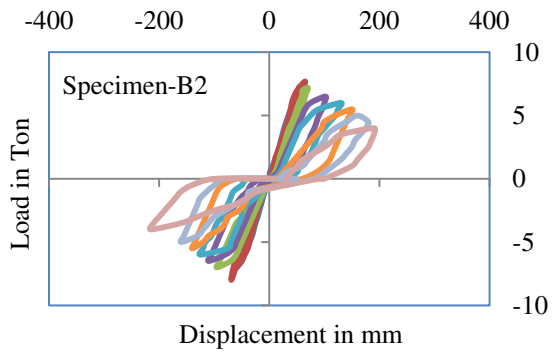

Figure 12. Load vs displacment (B2). 


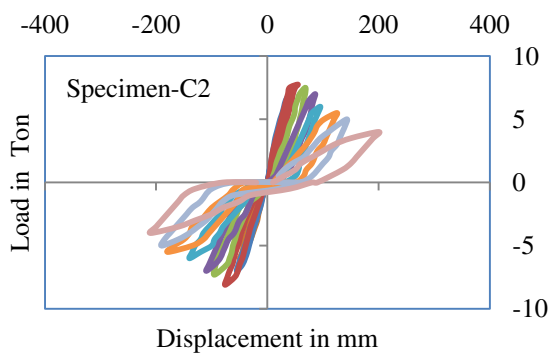

Figure 13. Load vs displacment (C2).

be less than $8 d_{b}$ or 6 in. (150 mm), for Type- 1 and Type-2 connections. As per IS-456 (2000), the development length $\left(L_{d}\right)$ of the hooked reinforcement bar should be computed as shown in the table 1 .

\subsection{Transverse reinforcement within the joint core}

The ACI-352 (2002) committee report recommends adequate lateral confinement of the concrete in the joint core for the shear demand in the form of spirals or rectangular hoops for both Type- 1 and Type- 2 joints. For Type- 2 joints, the total cross sectional area of transverse reinforcement within the joint in each direction should be at least equal to $A_{s h}$ and not less than $A_{s h}$ as given in the equation-1 $\left(301.6 \mathrm{~mm}^{2}\right.$ provided $\left.>228.82 \mathrm{~mm}^{2} \geq 71.57 \mathrm{~mm}^{2}\right)$.

$$
A_{s h}=0.3 \frac{S_{h} b_{c}^{\prime \prime} f_{c}^{\prime}}{f_{y h}}\left(\frac{A_{g}}{A_{c}}-1\right) \geq 0.09 \frac{S_{h} b_{c}^{\prime \prime} f_{c}^{\prime \prime}}{f_{y h}} .
$$

The center to center spacing between layers of transverse reinforcement $S_{h}$ should not exceed the least of $1 / 4$ of the minimum column dimension, six times the diameter of the longitudinal column bars to be restrained, and 6 in $(150 \mathrm{~mm}$.).

As per IS-13920 (1993) the area of cross section, $A_{s h}$ of the bar forming rectangular hoop, to be used as special confining reinforcement which shall not be less than $\left(241.30 \mathrm{~mm}^{2}<\right.$ $301.6 \mathrm{~mm}^{2}$ provided).

$$
A_{s h}=0.18 * S * h \frac{f_{c k}}{f_{y}}\left(\frac{A_{g}}{A_{k}}-1.0\right) .
$$

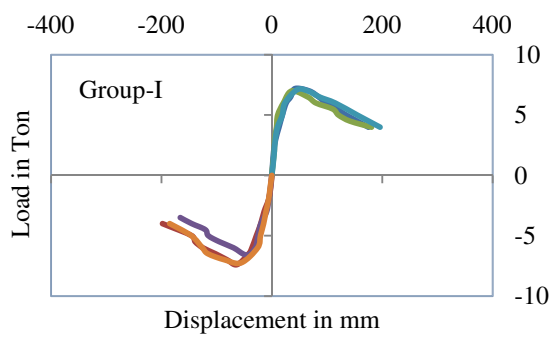

Figure 14. Peak load vs displacment. 


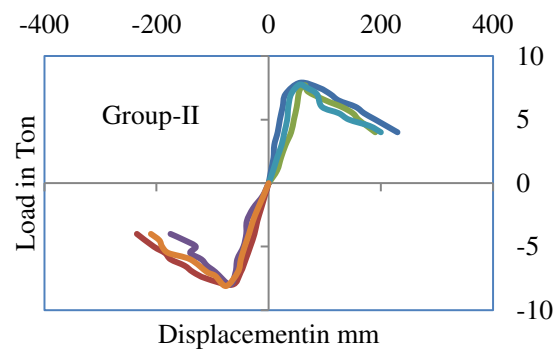

Figure 15. Peak load vs displacment.

\subsection{Joint shear strength}

For connections with beams framing in from perpendicular direction, the horizontal shear in the joint should be checked in beam direction. The design shear force $V_{u}$ should be computed on a horizontal plane at the mid height of the joint by considering the shear force on the boundaries of the free body of the joint as well as the normal tension and compression forces in the members into the joint, as shown in the figure 7.

The ACI-352 (2002) requirements for the nominal shear strength of the joint should be satisfied as per the below equations.

$$
\phi V_{n}=\phi * 0.083 \gamma \sqrt{f_{c}^{\prime}} b_{j} h_{c} \geq V_{u} .
$$

The horizontal joint shear force demand $V_{u}$ is calculated based on the amount of beam, slab and other reinforcement within the beam area as

$$
V_{u}=T_{b}-V_{c o l}=\alpha * f_{y} A_{s}-V_{c o l} .
$$

Shear in column calculated based on $\mathrm{Mpr}$ for beams

$$
V_{c o l}=\frac{M_{p r}}{h_{s t}} .
$$

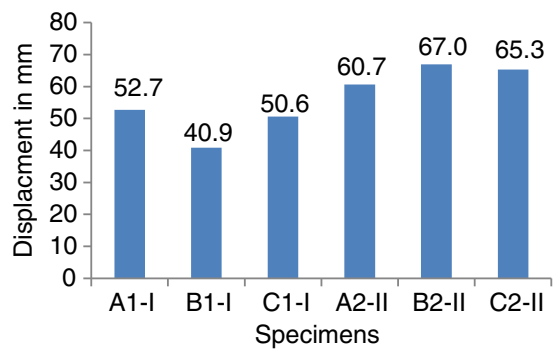

Figure 16. Displacment chart of the test specimens. 


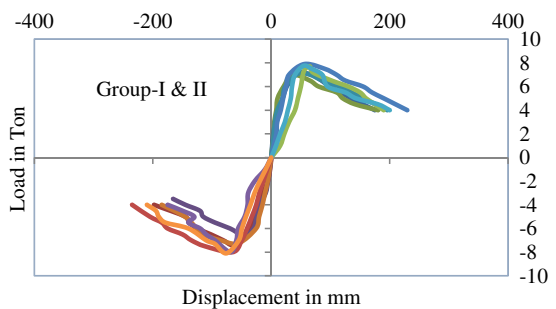

Figure 17. Peak load vs displacment (Group-I \& II).

\section{Test results and discussion}

\subsection{Lateral load versus lateral displacement}

The hysteresis loops behaviour of specimens A1, B1 and C1 in Group-I, A2, B2 and C2 in Group-II subjected to lateral load are indicated in figures 8-10 and figures 11-13 respectively. The corresponding peak load versus displacement behaviour is indicated in figures 14-15. It is observed that in Group-I, the average ultimate load carrying capacity of the specimens A1, B1 and $\mathrm{C} 1$ are $73.00 \mathrm{kN}, 68.00 \mathrm{kN}$ and $71.75 \mathrm{kN}$ with the corresponding lateral displacement of $52.72 \mathrm{~m}, 40.90 \mathrm{~mm}$ and $50.62 \mathrm{~mm}$ (as shown in figure 16) respectively. Among these A1 exhibits the maximum load carrying capacity which is higher than B1 by $6.85 \%$ and $1.71 \%$ slightly higher than $\mathrm{C} 1$.

It is observed that in Group-II, the average ultimate load carrying capacity of the specimens A2, B2 and C2 are $79.50 \mathrm{kN}, 78.50 \mathrm{kN}$ and $79.25 \mathrm{kN}$ with the corresponding lateral displacement of $60.66 \mathrm{~mm}, 67.00 \mathrm{~mm}$ and $65.29 \mathrm{~mm}$ (as shown in figure 16) respectively. Among these A2 exhibits the maximum load carrying capacity than B2 by $1.26 \%$ and $\mathrm{C} 2$ by $0.31 \%$.

It is seen from figures $17-18$ that specimens in Group-II show superior load carrying capacity (A1 by $8.18 \%, \mathrm{~B} 1$ by $13.38 \%$ and $\mathrm{C} 1$ by $9.46 \%$ ) when comparing to specimens in Group-I. From the above test results it can be inferred that the proposed additional X-cross bar increases the ultimate strength of exterior beam-column joint significantly.

\subsection{Behaviour in ductility}

It is essential that the beam-column joints in an earthquake resistant structure will behave in a ductile manner while subjected to several cycles of lateral loads in the inelastic range. Ductility is the property which allows the structure to undergo large deformation beyond the initial yield

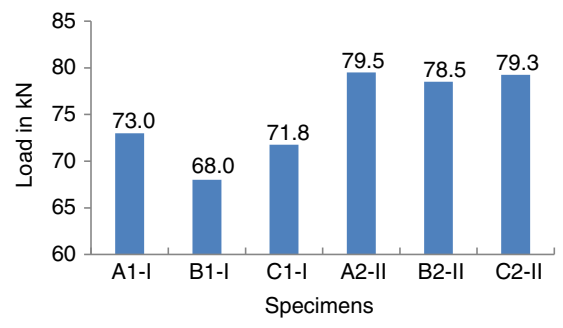

Figure 18. Loading capacity chart of the test specimens. 


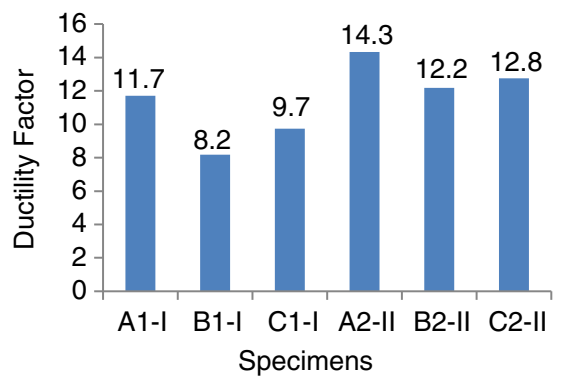

Figure 19. Ductility factor chart of the test specimens.

deformation without losing its strength abruptly. Ductility $(\mu)$ can be defined as the ratio of ultimate deflections $\left(\delta_{u}\right)$ to initial yielding deflection $\left(\delta_{y}\right) \cdot \mu=\left(\delta_{u} / \delta_{y}\right)$.

From figure 19, it is observed that Group-II specimens namely A2 (ACI-352 mechanical anchorage), B2 (ACI-318 $90^{\circ}$ bent hook anchorage) and C2 (IS-456 full anchorage) exhibit higher ductility than Group-I specimens namely A1, B1 and C1 by $18.31 \%, 32.84 \%$ and $23.67 \%$ respectively, wherein proposed additional X-cross bar joint core details are used in Group-II. Among these six specimens, A2 exhibits better performance. This combination of anchorage and joint details can be used in ductility demanding situations.

\subsection{Behaviour in stiffness}

In the case of reinforced concrete beam-column joints, stiffness of the joint gets degraded when the joint are subjected to reversal loading. During the reversal loading, concrete and reinforcement steel bars are subjected to several loading, unloading and reloading cycles. The joints initially develop micro cracks inside and it leads to lowering of energy limit of the materials thereby resulting in the increase of deformation inside the joints. This may consequently cause the reduction in the joint stiffness. Therefore it becomes essential to assess the degradation of stiffness in the beam-column joints subjected to reversal loading.

The stiffness behaviour of specimens referring to figure 20, the stiffness $(K)$ is calculated $K=$ $(P / \delta)$. Where ' $P$ ' is the peak average force and ' $\delta$ ' is the peak average displacement value, which are peak values of each hysteresis loops. Among specimens in Group-I and Group-II specimens $\mathrm{A} 1$ and A2 have higher stiffness values than specimens B1, C1, B2 and C2.

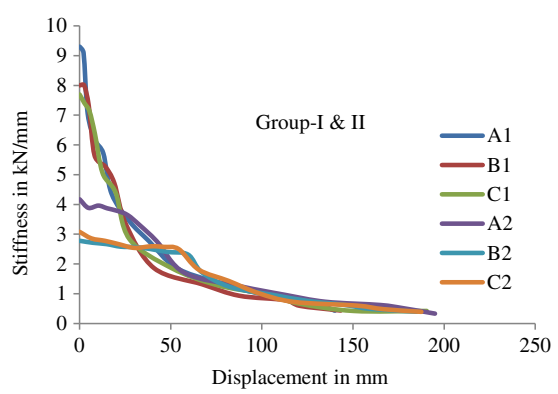

Figure 20. Stiffness vs displacment. 
Table 2. Observed yield load, ultimate load, ductility and stiffness of test specimens.

\begin{tabular}{|c|c|c|c|c|c|c|c|c|c|}
\hline \multirow{2}{*}{$\begin{array}{l}\text { Speci- } \\
\text { mens } \\
\text { name } \\
\text { and } \\
\text { groups }\end{array}$} & \multirow{2}{*}{$\begin{array}{c}\text { Yielding } \\
\text { displace- } \\
\text { ment } \\
\text { in } \mathrm{mm} \\
\left(\delta_{y}\right)\end{array}$} & \multicolumn{2}{|c|}{$\begin{array}{c}\text { Ultimate } \\
\text { load } \\
\text { in kN } \\
\left(\mathrm{P}_{u}\right)\end{array}$} & \multirow{2}{*}{$\begin{array}{l}\text { Average } \\
\text { ultimate } \\
\text { load in } \\
\mathrm{kN}\left(\mathrm{P}_{u}\right)\end{array}$} & \multicolumn{2}{|c|}{$\begin{array}{l}\text { Ultimate } \\
\text { displace- } \\
\text { ment } \\
\text { in mm } \\
\left(\delta_{u}\right)\end{array}$} & \multirow{2}{*}{$\begin{array}{c}\text { Average } \\
\text { displace- } \\
\text { ment for } \\
\text { ultimate } \\
\text { load in } \\
\mathrm{mm}\left(\delta_{u}\right)\end{array}$} & \multirow{2}{*}{$\begin{array}{c}\text { Average } \\
\text { displace- } \\
\text { ment } \\
\text { ductility } \\
\text { factor } \\
\mu=\delta_{u} / \delta_{y}\end{array}$} & \multirow{2}{*}{$\begin{array}{c}\text { Average } \\
\text { stiffness } \\
\mathrm{kN} / \mathrm{mm} \\
\mathrm{k}=P_{u} / \delta_{y} \\
\quad \text { in }\end{array}$} \\
\hline & & $\begin{array}{l}\text { Left } \\
\text { Side }\end{array}$ & $\begin{array}{l}\text { Right } \\
\text { Side }\end{array}$ & & $\begin{array}{l}\text { Left } \\
\text { Side }\end{array}$ & $\begin{array}{l}\text { Right } \\
\text { Side }\end{array}$ & & & \\
\hline A1-I & 4.50 & 72.00 & 74.00 & 73.00 & 42.13 & 63.30 & 52.715 & 11.714 & 16.222 \\
\hline B1-I & 5.00 & 70.00 & 66.00 & 68.00 & 35.96 & 45.85 & 40.905 & 8.181 & 13.600 \\
\hline C1-I & 5.20 & 71.00 & 72.50 & 71.75 & 45.63 & 55.60 & 50.615 & 9.734 & 13.798 \\
\hline A2-II & 4.23 & 79.00 & 80.00 & 79.50 & 56.00 & 65.32 & 60.660 & 14.340 & 18.794 \\
\hline B2-II & 5.50 & 77.00 & 80.00 & 78.50 & 65.00 & 69.00 & 67.000 & 12.182 & 14.273 \\
\hline C2-II & 5.12 & 77.50 & 81.00 & 79.25 & 54.63 & 75.96 & 65.295 & 12.753 & 15.479 \\
\hline
\end{tabular}

Table 2 shows only the average initial stiffness (stiffness $K=P_{u} / \delta_{y}$. wherein ' $P_{u}$ ' is the ultimate load and ' $\delta_{y}$ ' is the yielding displacement of the specimens). It has been observed from the experimental test results that among specimens in Group-I, specimen A1 is has the higher stiffness than specimens B1 and C1. In Group-II, specimen A2 is has the higher stiffness than specimens B2 and C2. The stiffness of specimens A2 is higher than A1 by $13.83 \%$. Among these two groups, the specimens in Group-II are having higher stiffness.

\subsection{Behaviour crack study and discussion}

On examination of crack pattern of figures 21 and 22, flexural cracks on the beam-column junction and shear cracks have developed on the column in all the specimens. Further to these cracks, the specimens B1 C1, B2 and C2 have $90^{\circ}$ bent tensile anchorage bars, which induce a compressive stress in the joint diagonally, forming a compression strut due to contact pressure under the bend. Tension tie developed in the joint perpendicular to the direction of the strut
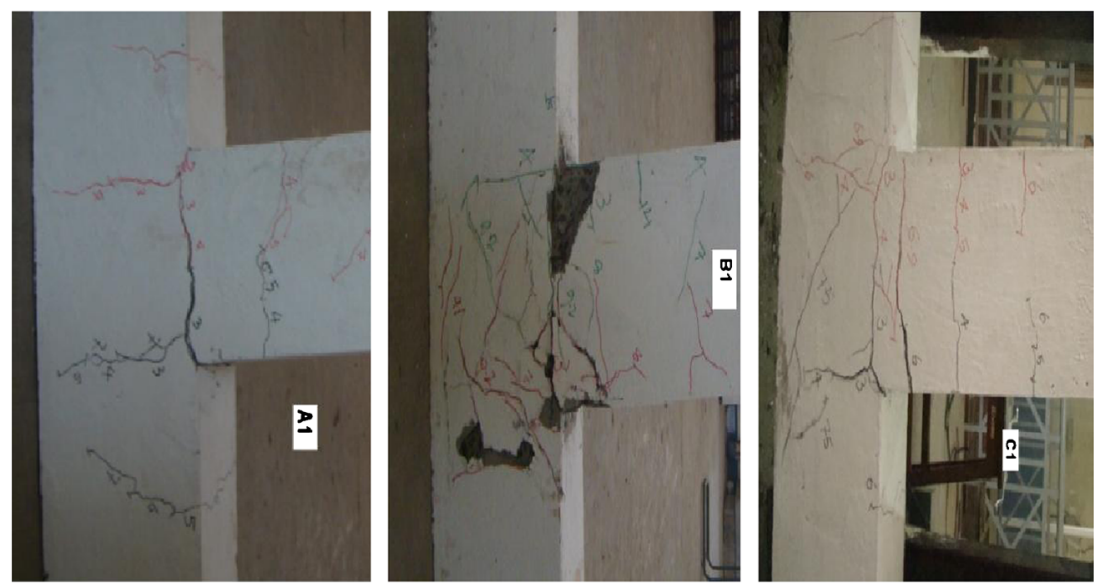

Figure 21. Crack pattern of group-I (A1, B1, C1). 

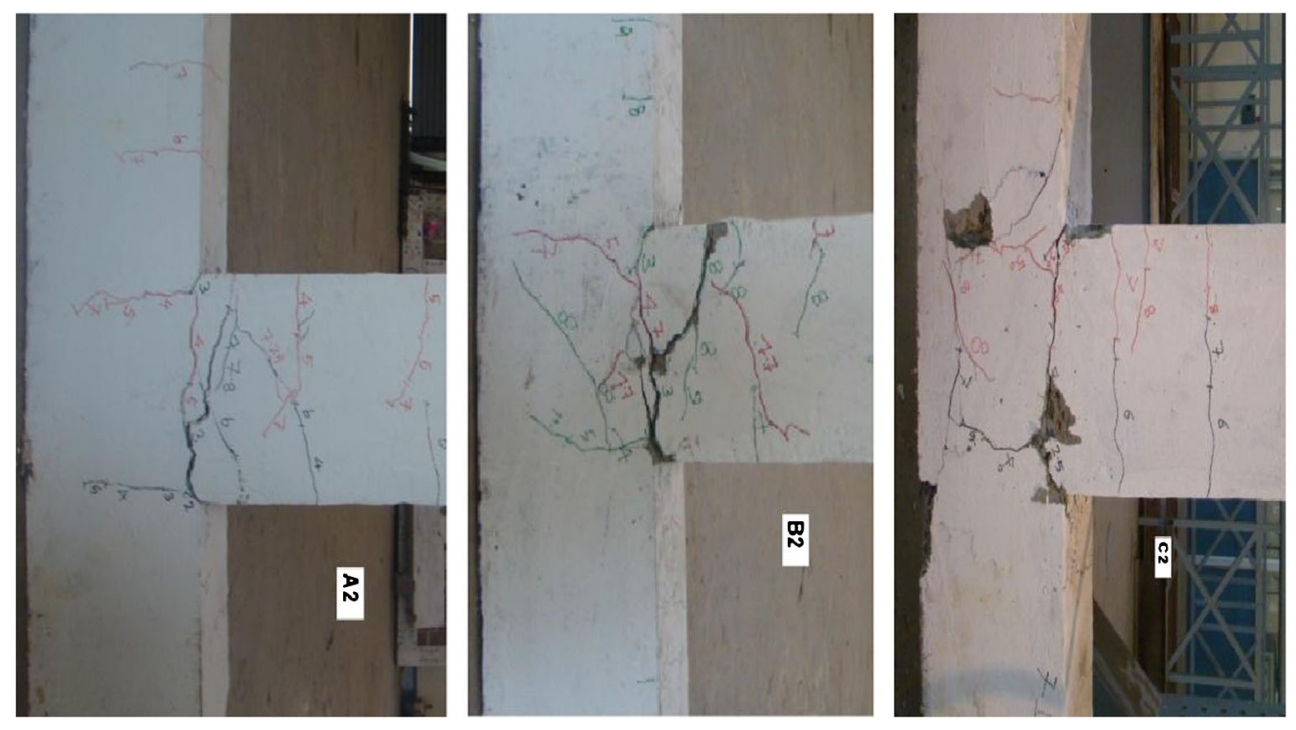

Figure 22. Crack pattern of group-II (A2, B2, C2).

induces a tensile stress. Diagonal cracks developed perpendicular to the direction of the diagonal tension tie in the joint shear panel area. Besides the wide open cracks in the junction, the concrete had also crushed and spalled out from the specimens B1, B2, C1 and C2 due to compressive force, the specimens A1 and A2 with mechanical anchorage shows the lesser crack pattern than other specimens using conventional joints details in Group-I and II without losing the strength, however specimen A2 with mechanical anchorage plus X-Cross bar, shows lesser cracks and much better control of crack capacity than other specimens. It can therefore be concluded that these types of anchorage with joint core details are much more effective in controlling beamcolumn joint than conventional details. It is apparent that the use of mechanical anchored bars is a viable alternative to use of standard $90^{\circ}$ hooks in exterior beam-column joints in seismic prone area. In addition easy to repair using FRP composite wraps techniques to restore the flexural strength, ductility of earthquake damaged concrete beam-column joints.

\section{Conclusions}

The following suggestions for the detailing of exterior beam-column joint of reinforced concrete structures in seismic prone areas are made from the knowledge gathered through the results of the experimental tests.

The specimens A1, A2 with T-type mechanical anchorage (ACI-352) are having a better performance than the specimens B1 and B2 with conventional $90^{\circ}$ hooks bent anchorage as per ACI-318 and the specimens C1 and C2 with full anchorage as per IS-456 without compromising with the load carrying capacity, ductility and stiffness demand. This arrangement of the reinforcement details in the exterior beam-column joint leads to reduction in the congestion of reinforcement. Mechanical anchorage (headed bar) is a viable alternative to the use of standard $90^{\circ}$ bent hooks in exterior beam-column joints in seismic prone area.

The specimen A2 is having better crack control capacity than other specimens. It can be concluded that the mechanical anchorage (headed bar) in combination with X-Cross bar is effective 
in controlling the beam-column joint yielding and ultimate failure than conventional joint core details. This combination of anchorage and joint detailing may be used in locations demanding low and moderate ductility situation.

\section{Symbols}

$A_{c}$ Area of column core measured from outside edge to outside edge of spiral or hoop reinforcement.

$A_{g}$ Gross area of column cross section.

$A_{s h}$ Area of the bar cross section (IS-Code).

$A_{s h}$ Total cross-sectional area of all legs of hoop reinforcement, including crossties, crossing a section having core dimension $b_{c}^{\prime \prime}$.

$A_{k}$ Area of confined concrete core in the rectangular hoop measured to its outside dimensions.

$A_{s}$ Area of tension reinforcement.

$b_{c}^{\prime \prime}$ Core dimension of tied column, outside to outside edge of transverse reinforcement bars, perpendicular to the transverse reinforcement area $A_{s h}$ being designed

$b_{j}$ Effective width of the joint transverse to the direction of shear.

$d_{b}$ Nominal diameter of bar.

$f_{c}$ ' Compressive strength of concrete.

$f_{c k}$ Characteristic compressive strength of concrete.

$f_{y}$ Yield stress of reinforcement.

$f_{y h}$ Yield stress of spiral, hoop, and crosstie reinforcement.

$h$ Longer dimension of the rectangular confining hoop measured to its outer.

$h_{c}$ Depth of the column.

$h_{s t}$ Height of the column.

$L_{d}$ Development length.

$L_{d h}$ Development length for a hooked bar, measured from the critical section to the outside edge of the hook extension.

$L_{d t}$ Development length for a headed bar, measured from the critical section to the outside end of the head.

$S_{h}$ Center-to-center spacing of hoops or hoops plus crossties.

$S$ Pitch of spiral or spacing of hoop, (the spacing of hoops used as special confining reinforcement shall not exceed $1 / 4$ of minimum member dimension but need not be less then $75 \mathrm{~mm}$ nor more than $100 \mathrm{~mm}$ ).

$T_{b}$ Tension force in the reinforcement.

$V_{n}$ Nominal shear strength of the joint.

$V_{c o l}$ Shear in the column calculated based on $M_{p r}$ for beam.

$\sigma_{s}$ Stress in bar $\left(0.87 * f_{y}\right)$ at the section considered at design load.

$\tau_{b d}$ Design bond stress of concrete (can be increased by $60 \%$ for deformed bars).

$\alpha$ Stress multiplier for longitudinal reinforcement at joint-member interface for Type-2, $\alpha \geq$ 1.25 .

$\gamma$ Shear strength factor reflecting confinement of joint by lateral member.

$\varnothing$ Nominal diameter of the bar. 


\section{Acknowledgements}

The authors would like to thank the Department of Civil Engineering, Mepco Schlenk Engineering College, Sivakasi, Tamil Nadu, India for extending the facilities.

\section{References}

ACI-352 2002 Recommendations for design of beam-column connections in monolithic reinforced concrete structures (reported by Joint ACI-ASCE committee 352). USA: American concrete Institute

ACI-318 2011 Building code requirements for structural concrete and commentary (reported by ACI committee 318). Farmington Hills, Michigan, USA: American Concrete Institute

Bindhu K R, Jeya K P and Manicka Selvam V K 2008 Seismic resistance of exterior beam-column joints with non-conventional confinement reinforcement detailing. Struct. Eng. Mech. 30(6): 733-761

Chutarat N and Aboutaha R S 2003 Cyclic response of exterior reinforcement concrete beam-column joints reinforced with headed bars-experimental investigation. ACI Struct. J. 100(2): 259-264

Chun S-C, Lee S-H, Kang T H-K, Oh B and Wallace J W 2007 Mechanical anchorage in exterior beamcolumn joints subjected to cyclic loading. ACI Struct. J. 104(1): 102-113

IS-456 2000 Indian standard plain and reinforced concrete code of practice (Bureau of Indian Standards). New Delhi, India

IS-13920 1993 Indian standard ductile detailing of reinforced concrete structures subjected to seismic forces code of practice (Bureau of Indian Standards), New Delhi, India

Kang T H-K, Shin M, Mitra N and Bonacci J F 2009 Seismic design of reinforced concrete beam-column joints with headed bars. ACI Struct. J. 106(6): 868-877

Kang T H-K, Ha S-S and Choi D U 2010 Bar pullout tests and seismic tests of small-headed bars in beam-column joints. ACI Struct. J. 107(1): 32-42

Lee H J and Yu Si Ying 2009 Cyclic response of exterior beam-column joints with different anchorage methods. ACI Struct. J. 106(3): 329-339

Misir I S and Kahraman S 2013 Strengthening of non-seismically detailed reinforced concrete beamcolumn joints using SIFCON blocks. Sadhana - Acad. Proc. Eng. Sci. 38(1): 69-88

Murty C V R, Rai D C, Bajpai K K and Jain Sudhir K 2003 Effectiveness of reinforcement details in exterior reinforcement concrete beam-column joints for earthquake resistance. ACI Struct. J. 100(2): 149-156

Paulay T 1989 Equilibrium criteria for reinforcement concrete beam-column joints. ACI Struct. J. 86(6): 635-643

Park R and Paulay T 1975 Reinforced concrete structures. New York: John Wiley \& Sons

Sagbas G, Vecchio F J and Christopoulos C 2011 Computational modeling of the seismic performance of beam-column sub assemblies. J. Earthq. Eng. 15(4): 640-663

Tsonos A G, Tegos I A and Penelis G 1993 Seismic Resistance of Type 2 Exterior beam-column joints reinforcement with inclined bars. ACI Struct. J. 89(1): 3-12

Uma S R and Sudhir K Jain 2006 Seismic design of beam-column joints on RC moment resisting framesreview of codes. Struct. Eng. Mech. 23(5): 579-597

Wallance J W, McConnell S W, Guta P and Cote P A 1998 Used of headed reinforcement in beam-column joints subjected to earthquake loads. ACI Struct. J. 95(5): 590-606 